\title{
Stem Cell Therapy in Wound Healing
}

\author{
András Mester ${ }^{1,2}$, Diana Opincariu'1,2, Imre Benedek ${ }^{1,2}$, István Benedek ${ }^{1,3}$ \\ ${ }^{1}$ University of Medicine and Pharmacy, Tîrgu Mureș, Romania \\ ${ }^{2}$ Center of Advanced Research in Multimodality Cardiac Imaging, Cardio Med Medical Center, Tîrgu Mureș, Romania \\ 3 Clinic of Hematology and Bone Marrow Transplantation Unit, Tîrgu Mureș, Romania
}

\section{CORRESPONDENCE}

\section{Diana Opincariu}

Str. Gheorghe Marinescu nr. 38

540139 Tîrgu Mureș, Romania

Tel: +40 265215551

E-mail: diana.opincariu@yahoo.ro

\section{ARTICLE HISTORY}

Received: October 14, 2017

Accepted: November 5, 2017
András Mester • Str. Gheorghe Marinescu nr. 38 540139 Tîrgu Mureș, Romania. Tel: +40 265215551. E-mail: andras.mester@yahoo.com

Imre Benedek • Str. Gheorghe Marinescu nr. 38 540139 Tîrgu Mureș, Romania. Tel: +40 265215551. E-mail: imrebenedek@yahoo.com

István Benedek • Str. Gheorghe Marinescu nr. 38 , 540139 Tîrgu Mureș, Romania. Tel: +40 265215551. E-mail: istvan.benedek@umftgm.ro

\begin{abstract}
Wound healing is a complex restorative process of the altered cutaneous tissue, which is impaired by numerous local and systemic factors, leading to chronic non-healing lesions with few efficient therapeutic options. Stem cells possess the capacity to differentiate into various types of cell lines. Furthermore, stem cells are able to secrete cytokines and growth factors, modulating inflammation and ultimately leading to angiogenesis, fibrogenesis, and epithelization. Because of their paracrine activity, these cells are able to attract other cell types to the base of the wound, improving the formation of new skin layers. Mesenchymal stem cells derived from the adipose tissue, bone marrow, and placenta, offer numerous ways of implementation. The process of harvesting, growing, and administrating stem cells depends on the site and type of the cells, but recent trial results showed improvement of wound healing independent of the administration site. Bioengineered skin substitutes are validated for treatment of chronic wounds with direct application on the skin surface. These offer physical scaffolding for the migrating cells and promote secretion of growth factors, thus facilitating rapid wound healing. Obtaining further clinical data is essential, but stem cell therapy may become a first-line therapeutic choice for the treatment of non-healing chronic wounds.
\end{abstract}

Keywords: stem cell therapies, non-healing wounds, bioengineered skin

\section{INTRODUCTION}

Chronic impaired wound healing is still a challenging therapeutic task for healthcare experts. It involves a vast interdisciplinary approach from surgical, medical, dermatological, diabetic, general practitioner specialist, and nursing staff for longterm success. Aging and various medical conditions create a physiopathological ground for impaired wound healing, leading to a long and exhausting restorative process, which often remains unsuccessful and greatly affects the quality of life of these patients. ${ }^{1,2}$ As the aging population is growing worldwide, it is expected that the burden of chronic wounds will increase significantly in the next few decades. ${ }^{3}$ Approximately $1 \%$ of the population suffers from non-healing wounds, generating tremendous costs for healthcare systems. ${ }^{4,5}$ Despite the multitude of recently developed therapeutic options for these patients, the results are still unsatisfactory. Multiple clinical and preclinical trials are under development worldwide for the assessment of novel therapeutic methods in chronic wound healing. ${ }^{6,7}$ 
As a result of translational medicine research progresses, stem cells have emerged as a viable alternative for the treatment of this complex pathology for enhancement of tissue regeneration. ${ }^{8}$ Stem cell therapy has already been intensely studied in organ damage repair and regeneration in numerous diseases. ${ }^{9,10}$ One of the most promising results was obtained in the field of cardiovascular diseases, namely recovery in the post-myocardial infarction phase and critical limb ischemia. ${ }^{11-13}$ The major drawback of stem cell-based treatment is represented by the difficulties of adequate stem cell population selection, delivery, and the prevention of immune and tumor responses. ${ }^{14}$

The aim of this clinical update is to summarize the current applications of stem cell therapies in the treatment of chronic wounds.

\section{PATHOPHYSIOLOGY OF IMPAIRED WOUND HEALING}

Regeneration and healing of the altered cutaneous tissue is a complex, well-organized process. After platelet aggregation and clot formation in the hemostasis phase, the inflammatory process is activated by chemokines, which attract neutrophils, lymphocytes, and monocytes that release inflammatory cytokines and growth factors. ${ }^{15}$ Chronic wounds exhibit a prolongation of the inflammatory phase, which ultimately leads to failure of the healing process due to alteration of the extracellular matrix. ${ }^{16}$ The proliferative and resolutive phase of wound healing is characterized by angio- and fibrogenesis, with collagen formation and reepithelization. Chronic wounds are usually defined by deficient vascularization, with reduction of angiogenesis and formation of fibrotic and epithelial cells. ${ }^{17}$ All stages can be altered by aging and by the presence of local factors, such as infections, ischemia, radiation, traumas, toxins, as well as systemic factors such as diabetes, cancers, drugs, neuropathies, smoking, or alcoholism. ${ }^{18}$

\section{THE ROLE OF STEM CELLS IN WOUND HEALING}

Given their pluripotent and self-renewing characteristics, stem cells are able to differentiate into different types of mature functional tissues. ${ }^{19}$ Their potential in the epithelial healing of chronic wounds lies in their capacity to secrete cytokines that promote angiogenesis, cell proliferation, and tissue regeneration. The development of bioengineered tissues impregnated with stem cells stays at the basis of this novel chronic wound care therapy. ${ }^{20}$ One of the most important factors that affect the success of stem cell therapy is represented by the selection of stem cell populations.

\section{Mesenchymal stem cells}

Mesenchymal stem cells (MSC) can be isolated from various types of tissues including bone marrow, umbilical cord blood, and adipose tissue, and possess the ability of good adherence to plastic materials. ${ }^{21}$ These stem cells can be delivered topically or systemically. ${ }^{22}$ In addition to their ability to differentiate into various cell lines and to promote angiogenesis, MSCs present potent immunomodulatory and immunoregulatory characteristics, thus coordinating the inflammatory process, reducing scarring, and modulating fibrosis. This is achieved by releasing multiple chemokines that act as mediators. ${ }^{23,24}$ The efficiency of MSCs in the treatment of critical limb ischemia has already been proven safe and efficient. ${ }^{25}$ Currently there is no evidence of any clinical benefit regarding the tissue origins of stem cells used in wound healing.

\section{Adipose stem cells}

Adipose stem cells (ASC) are pluripotent MSCs, which can be extracted from adipose tissue, are easily harvested by liposuction or minimal-invasive surgical excision and can be preserved for up to six months. Another advantage of adipose tissue over other extraction sites of MSCs comes from the fact that a large number of stem cells can be yielded from this type of tissue compared to other sites (e.g., 40fold higher compared to bone marrow) and can be transplanted to autologous or allogeneic hosts. ${ }^{26}$ Autologous ASC transplantation is well tolerated and it is proven to be safe in terms of malignant transformation. ${ }^{27}$ Given the rich amount of easily accessible fat tissue in the body and their angiogenic and paracrine potential, ASCs are widely used MSCs in wound healing research..$^{28,29}$ ASCs improve wound healing by the secretion of mediators such as platelet derived growth factor (PDFG), vascular endothelial growth factor (VEGF), hepatocyte growth factor (HGF), fibronectin, and collagen I, stimulating angiogenesis and smaller scar formation..$^{30}$ Because of their paracrine effect, ASCs stimulate other cells and recruit stem cells to form fibroblasts, keratocytes, and endothelial cells, and down-regulate the inflammatory response, therefore leading to improved epithelization. ${ }^{18,31}$ Numerous studies have analyzed the effect of ASCs in different types of chronic wound healing, with positive histological and clinical results in skin cancer-related wounds. ${ }^{32}$ Ischemic and irradiation wounds are also an important topic in chronic wound 
healing, with different results so far.33Another broadly researched application of ACSs is represented by diabetic wounds. Recent preclinical studies suggest that ASCs combined with artificial skin enhances diabetic wound healing through the secretion of growth factors and new vessel formation in diabetic rats. An improvement was observed in capillary formation, fibroblast proliferation, epithelization, and wound contraction compared to control groups. ${ }^{34-36}$ Encouraged by the positive preclinical results, many ongoing clinical trials are being carried out, but few results have been published so far about wound healing. However, the results of other applications of ASCs (e.g., osteogenic defect healing and Crohn's disease fistulas) are promising. ${ }^{37,38}$

\section{Bone marrow stem cells}

Bone marrow is one of the most frequently used sites for stem cell extraction. These cells play an important role in each phase of wound healing, thus they are targeted as viable therapeutic alternatives in chronic wound healing. ${ }^{39}$ Bone marrow-derived stem cells also hold the property to adhere to plastic materials and can be applied directly on the surface of the wounds, injected in the edges of the wound, or administered systemically. ${ }^{40}$ Randomized controlled clinical trials have reported positive outcomes with topical and intramuscular delivery of bone marrow-derived MSCs and autologous biograft in chronic diabetic wounds. Significant contraction in wound size $\left(7.26 \pm 1.41 \mathrm{~cm}^{2}\right.$ vs. $\left.2 \pm 0.98 \mathrm{~cm}^{2}, \mathrm{p}<0.001\right)$ was observed at 12 weeks, with prolonged pain-free walking distance $(38.33 \pm 17.68 \mathrm{~m}$ vs. $284 \pm 212 \mathrm{~m}, \mathrm{p}<0.001) .{ }^{41}$ Another study, which used bone marrow-derived stem cells applied with a polymer spray on surgical excision chronic wounds, has demonstrated the efficiency of this therapy, leading to the repair of the epithelial surface in eight weeks. ${ }^{42}$ An enhancement of the vascularity and growing of the dermal layer was observed in a study in which the researchers had injected bone marrow-derived stem cells in the edges of the wound in patients with diabetic foot. This was accompanied by a reduction in wound size. ${ }^{43}$ Autologous bone marrow-derived stem cells have led to complete wound healing in a study that included patients with leg ulcers that lasted longer than one year despite conventional treatment. ${ }^{44}$ In a randomized controlled trial where intramuscular bone marrow-derived stem cell were administered for diabetic patients with critical limb ischemia and foot ulcers, there was a significantly higher healing rate and pain-free walking distance recorded during the 24-week follow-up period. ${ }^{45}$

\section{Placental and embryonic tissue}

Placental tissue is an excellent source of stem cells, with pluripotent differentiation and immunomodulatory capacity, which makes it a suitable alternative for the bioengineering of skin substitutes that can be used for the treatment of chronic wounds. ${ }^{46}$ Furthermore, growth factors and extracellular matrix that are essential for the natural wound healing process are also secreted by the placenta. ${ }^{47}$ Preclinical investigations are carried out to determine the safety and efficiency of this method. Bioengineered skin substitutes are available from the human neonatal fibroblast-dermis, which promotes cell migration and, through a paracrine effect and secretion of growth factors, enhances epithelization. It also offers physical scaffolding for migrating cells into the base of the wound, helping the recovery and healing of chronic ulcers. Randomized trials have proved the efficacy of these skin substitutes in chronic diabetic ulcers, with significantly higher wound closure rates compared to controls at 12 weeks (30\% vs. $18.3 \%$, $\mathrm{p}=0.02) .{ }^{48,49}$ Another bioengineered skin substitute is derived from neonatal foreskin, and it is approved for clinical use, being based on a bilayer structure of fibroblasts and keratocytes that facilitates the migration of monocytes to the wound base and the secretion of growth factors such as PDGF, fibroblast growth factor (FGF), or granulocyte colony-growth factor. ${ }^{50}$ These factors enable cell integration and allow vascular ingrowth, thus increasing and accelerating chronic wound healing. The published results of recent clinical trials are encouraging and have proved the efficacy of this treatment option in patients with diabetic foot ulcers and venous leg ulcers. ${ }^{51,52}$ A median of 61 days was recorded until complete wound healing vs. 181 days in the control group ( $\mathrm{p}=0.003)$ in patients with venous leg ulcer. ${ }^{53}$

\section{PROSPECTS OF STEM CELLS IN WOUND HEALING}

The origin of stem cells, the process of harvesting, preservation, and manipulation of cell lines, as well as their use is still under strict regulations both in Europe and in the United States, and they raise ethical controversies in terms of research and clinical use. ${ }^{54}$ Another limitation of stem cell therapy is linked to the huge costs of manufacturing, resourcing, and preservation of cell lines. Promising results of current stem cell therapies are encouraging investments in this flourishing research field, which leads to the emergence of new preclinical and clinical trials, which may transform it into a widely accessible therapeutic method. 


\section{CONCLUSIONS}

Despite many current therapeutic options, chronic wounds still remain a great concern for many healthcare professionals, and the number of these patients is expected to grow in the future due to the aging population and increasing incidence of diabetes. Stem cell therapy holds the potential of clinical improvement for these patients, due to its capacity of tissue regeneration, and direct and paracrine activity. A considerable number of stem cell types are used in preclinical and clinical studies with encouraging results, but further trials are needed to validate this therapeutic option.

\section{CONFLICT OF INTEREST}

Nothing to declare.

\section{REFERENCES}

1. Boulton AJ, Vileikyte L, Ragnarson-Tennvall G, Apelqvist J. The global burden of diabetic foot disease. Lancet. 2005;366:1719-1724.

2. Rando TA. Stem cells, ageing and the quest for immortality. Nature 2006;441:1080-1086.

3. Sen CK, Gordillo GM, Roy S, et al. Human skin wounds: a major and snowballing threat to public health and the economy. Wound Repair Regen. 2009;17:763-771.

4. Crovetti G, Martinelli G, Issi M, et al. Platelet gel for healing cutaneous chronic wounds. Transfus Apher Sci. 2004;30:145-151.

5. Simka M, Majewski E. The social and economic burden of venous leg ulcers-focus on the role of micronized purified flavonoid fraction adjuvant therapy. Am J Clin Dermatol. 2003;4:573-581.

6. Li MD, Atkins H, Bubela T. The global landscape of stem cell clinical trials. Regen Med. 2014;9:27-39.

7. Kanji S, Das H. Advances of Stem Cell Therapeutics in Cutaneous Wound Healing and Regeneration. Mediators of Inflammation. 2017;2017:5217967.

8. Zomer HD, Trentin AG Skin wound healing in humans and mice: Challenges in translational research. J Dermato/ Sci. 2017; pii:S0923-1811(17)31013-7.

9. Körbling M, Estrov Z. Adult stem cells for tissue repair-a new therapeutic concept? N Engl J Med. 2003;349:570-582.

10. Mimeault M, Hauke R, Batra S. Stem cells: a revolution in therapeuticsrecent advances in stem cell biology and their therapeutic applications in regenerative medicine and cancer therapies. Clin Pharmacol Therap. 2007;82:252-264.

11. Benedek I, Bucur O, Benedek T. Intracoronary infusion of mononuclear bone marrow-derived stem cells is associated with a lower plaque burden after four years. J Atheroscler Thromb. 2014;21:217-229.

12. Gremmels H, Teraa M, Quax PH, den Ouden K, Fledderus JO, Verhaa MC. Neovascularization capacity of mesenchymal stromal cells from critical limb ischemia patients is equivalent to healthy controls. Mol Ther. 2014;22:1960-1970.

13. Madaric J, Klepanec A, Valachovicova $M$, et al. Characteristics of responders to autologous bone marrow cell therapy for no-option critical limb ischemia. Stem Cell Res Ther. 2016;7:116.

14. Duscher D, Barrera, Wong VW, et al. Stem Cells in Wound Healing: The Future of Regenerative Medicine? A Mini-Review. Gerontology. 2016;62:216-225

15. Gosain A, DiPietro LA. Aging and wound healing. World J Surg. 2004;28:321-326

16. Menke NB, Ward KR, Witten TM, Bonchev DG, Diegelmann RF. Impaired wound healing. Clin Dermatol. 2007;25:19-25.

17. Mansbridge J. Commercial considerations in tissue engineering. J Anat. 2006;209:527-532

18. Hassan WU, Greiser U, Wang W. Role of adipose-derived stem cells in wound healing. Wound Repair Regen. 2014;22:313-325.
19. Behr B, Ko SH, Wong VW, Gurtner GC, Longaker MT. Stem cells. Plast Reconstr Surg. 2010;126:1163-1171.

20. Garg RK, Rennert RC, Duscher D, et al. Capillary force seeding of hydrogels for adipose-derived stem cell delivery in wounds. Stem Cells Trans/ Med. 2014;3:1079-1089.

21. Rustad KC, Wong VW, Sorkin M, et al. Enhancement of mesenchymal stem cell angiogenic capacity and stemness by a biomimetic hydrogel scaffold. Biomaterials. 2012:33:80-90.

22. Yoshikawa T, Mitsuno $H$, Nonaka I, et al. Wound therapy by marrow mesenchymal cell transplantation. Plast Reconstr Surg. 2008;121:860-877.

23. Ren G, Zhang L, Zhao X, et al. Mesenchymal stem cell-mediated immunosuppression occurs via concerted action of chemokines and nitric oxide. Cell Stem Cell. 2008;2:141-150.

24. Hu MS, Rennert RC, McArdle A, et al. The role of stem cells during scarless skin wound healing. Adv Wound Care. 2014;3:304-314.

25. Procházka V, Gumulec J, Jalůvka F, et al. Cell therapy, a new standard in management of chronic critical limb ischemia and foot ulcer. Cell Transplant. 2010;19:1413-1424.

26. Kern S, Eichler H, Stoeve J, Kluter H, Bieback K. Comparative analysis of mesenchymal stem cells from bone marrow, umbilical cord blood, or adipose tissue. Stem Cells. 2006; 24:1294-1301.

27. Kolle SF, Fischer-Nielsen A, Mathiasen AB, et al. Enrichment of autologous fat grafts with ex-vivo expanded adipose tissue derived stem cells for graft survival: a randomized placebo-controlled trial. Lancet. 2013;382:1113-1120.

28. Casteilla L, Planat-Benard V, Laharrague P, Cousin B. Adipose-derived stromal cells: Their identity and uses in clinical trials, an update. World J Stem Cells. 2011:3:25-33.

29. Zuk P. The ASC: Critical Participants in Paracrine-Mediated Tissue Health and Function. Available at: https://www.intechopen.com/ books/regenerative-medicine-and-tissue-engineering/the-asc-criticalparticipants-in-paracrine-mediated-tissue-health-and-function.

30. Park BS, Jang KA, Sung JH, et al. Adipose-derived stem cells and their secretory factors as a promising therapy for skin aging. Dermatol Surg. 2008;34:1323-1326

31. Amos PJ, Kapur SK, Stapor PC, et al. Human adipose-derived stromal cells accelerate diabetic wound healing: impact of cell formulation and delivery. Tissue Eng Part A. 2010;16:1595-1606.

32. Rigotti G, Marchi A, Galiè M, et al. Clinical treatment of radiotherapy tissue damage by lipoaspirate transplant: a healing process mediated by adipose-derived adult stem cells. Plast Reconstr Surg. 2007;119:14091422.

33. Haubner F, Ohmann E, Pohl F, et al. Wound healing after radiation therapy: review of the literature. Radiat Oncol. 2012;7:162

34. Kato Y, Iwata T, Washio K, et al. Creation and Transplantation of an Adiposederived Stem Cell (ASC) Sheet in a Diabetic Wound-healing Model. J Vis Exp. 2017. doi: 10.3791/54539.

35. Maharlooei MK, Bagheri M, Solhjou Z, et al. Adipose tissue derived mesenchymal stem cell (AD-MSC) promotes skin wound healing in diabetic rats. Diabetes Res Clin Pract. 2011;93:228-234.

36. Cianfarani F, Toietta G, Di Rocco G, et al. Diabetes impairs adipose tissuederived stem cell function and efficiency in promoting wound healing. Wound Repair Regen. 2013;21:543-553.

37. Mesimäki K, Lindroos B, To"rnwall J, et al. Novel maxillary reconstruction with ectopic bone formation by GMP adipose stem cells. Int J Oral Maxillofac Surg. 2009;38:201-209

38. Garcia-Olmo D, Herreros D, Pascual M, et al. Treatment of enterocutaneous fistula in Crohn's disease with adipose-derived stem cells: a comparison of protocols with and without cell expansion. Int J Colorectal Dis. 2009;24:27-30.

39. Rodriguez-Menocal L, Shareef S, Salgado M, Shabbir A, Van Badiavas E. Role of whole bone marrow, whole bone marrow cultured cells, and mesenchymal stem cells in chronic wound healing. Stem Cell Res Ther. 2015;6:24.

40. Maxson S, Lopez EA, Yoo D, Danilkovitch-Miagkova A, Leroux MA. Concise review: role of mesenchymal stem cells in wound repair. Stem Cells Trans/ Med. 2012;1:142-149.

41. Dash NR, Dash SN, Routray P, Mohapatra S, Mohapatra PC. Targeting non-healing ulcers of lower extremity in human through autologous bone marrow-derived mesenchymal stem cells. Rejuvenation Res. 2009;12:359366 .

42. Falanga $\mathrm{V}$, Iwamoto $\mathrm{S}$, Chartier $\mathrm{M}$, et al. Autologous bone marrowderived cultured mesenchymal stem cells delivered in a fibrin spray accelerate healing in murine and human cutaneous wounds. Tissue Eng. 2007:13:1299-1312. 
43. Vojtassák J, Danisovic L, Kubes M, et al. Autologous biograft and mesenchymal stem cells in treatment of the diabetic foot. Neuro Endocrinol Lett. 2006;27:134-137.

44. Badiavas EV, Falanga V. Treatment of chronic wounds with bone marrowderived cells. Arch Dermatol. 2003;139: 510-516.

45. Lu D, Chen B, Liang Z, et al. Comparison of bone marrow mesenchymal stem cells with bone marrow-derived mononuclear cells for treatment of diabetic critical limb ischemia and foot ulcer: a double-blind, randomized, controlled trial. Diabetes Res Clin Pract. 2011;92:26-36.

46. Banas RA, Trumpower C, Bentlejewski C, Marshall V, Sing G, Zeevi A. Immunogenicity and immunomodulatory effects of amnion-derived multipotent progenitor cells. Hum Immunol. 2008;69:321-328.

47. Yoo D, Jansen $T$, Kuang $J$, et al. Characterization of novel human mesenchymal stem cell-containing skin substitutes for the treatment of wounds. Ostomy Wound Manage. 2011;57:71.

48. Bieback K, Brinkmann I. Mesenchymal stromal cells from human perinatal tissues: From biology to cell therapy. World J Stem Cells. 2010;2:81-92.
49. Marston WA, Hanft J, Norwood P, Pollak R. The efficacy and safety of Dermagraft in improving the healing of chronic diabetic foot ulcers: results of a prospective randomized trial. Diabetes Care. 2003;26:1701-1705.

50. Navsaria HA, Myers SR, Leigh IM, McKay IA. Culturing skin in vitro for wound therapy. Trends Biotechnol. 1995;13:91-100.

51. Snyder RJ, Shimozaki K, Tallis A, et al. A Prospective, Randomized, Multicenter, Controlled Evaluation of the Use of Dehydrated Amniotic Membrane Allograft Compared to Standard of Care for the Closure of Chronic Diabetic Foot Ulcer. Wounds. 2016;28:70-77.

52. Stone RC, Stojadinovic O, Rosa AM, et al. A bioengineered living cell construct activates an acute wound healing response in venous leg ulcers. Sci Trans/ Med. 2017; pii:eaaf8611.

53. Falanga $\mathrm{V}$, Margolis $\mathrm{D}$, Alvarez $\mathrm{O}$, et al. Rapid healing of venous ulcers and lack of clinical rejection with an allogeneic cultured human skin equivalent. Human Skin Equivalent Investigators Group. Arch Dermatol. 1998;134:293-300.

54. Simonacci F, Bertozzi N, Raposio E. Off-label use of adipose-derived stem cells. Ann Med Surg (Lond). 2017;24:44-51. 